\title{
Availability of Educational Facilities to Improve Academic Performance of Students in Business Education
}

\author{
Olayemi, A.E*, Ige, S.M \\ School of Vocational and Technical Education, Department of Business Education, College of Education, Ikere \\ Ekiti, Ekiti State
}

*Corresponding Author: Olayemi, A.E, School of Vocational and Technical Education, Department of Business Education. College of Education. Ikere Ekiti. Ekiti State

\begin{abstract}
The study examined the availability of educational facilities to improve academic performance of business education students in college of education, ikere Ekiti. The descriptive research design of a survey was adopted for the study. The population of the study was made up of 374 Business education students in College of Education, Ikere Ekiti. The sample of the study was 100 Business Education students selected using simple random sampling technique. A well-structured questionnaire was the instrument used for the study, the questionnaire items were structured in a four-point Likert rating scale and it was validated by experts for face structure. The reliability of the instrument was determined. The reliability coefficient of 0.62 was obtained using the Cronbach alpha coefficient which indicated that the instrument was reliable to collect the necessary data for the study. Descriptive statistics was used to analyze the research questions. The study concluded that there are no adequate educational facilities such as modern equipment such as projector, computer, and lecture clips for practical work to enhance effective teaching and learning in order to improve students' academic performance. Therefore, this study recommends that adequate educational facilities should be made available in the institution in order to guarantee better academic performance of business education students.
\end{abstract}

\section{INTRODUCTION}

The role of educational facilities in qualitative education cannot be overemphasized because school facilities are a potential factor to quantitative education. It makes goals of teaching and learning to be achievable especially when there is adequate provision of instructional facilities. There is no doubt that good educational facilities support the educational enterprises thereby affects academic performance. Cotton, (2001) has shown that clean air, good light and a small quite, comfortable, and safe learning environment are important for academic achievement. However, the cry about the falling of education standard in the country as is attributed to the inadequate educational facilities in the tertiary institutions. Some of these facilities include school facilities which play a vital role in the actualization of educational goals and objectives by satisfying the physical and emotional needs of the staffs and students of the school. School facilities can be regarded as the items which make teaching and learning possible and easier in the school.

According to Osuji (2016) effective educational facility is responsive to the changing programs of educational delivery, and at a minimum should provide a physical environment that is comfortable, safe, secure, accessible, well illuminated, well ventilated, and aesthetically pleasing. However, he further educational facility consists of not only the physical structure and the variety of building systems, such as mechanical, plumbing, electrical and power, telecommunications, security, and fire suppression systems. The facility also includes furnishings, materials and supplies, equipment and information technology, as well as various aspects of the building grounds, namely, athletic fields, playgrounds, areas for outdoor learning, and vehicular access and parking (Osuji, 2016). Educational facilities had a major impact on academic performance. For instance schools with inadequate building, no science labs, inadequate ventilation and faulty heating systems affect students' performance (Stricherz, 2000, Lewis, 2001). Educational facilities can be referred to as the human and physical resources that are needed or used in the institutions in order to aid learning and teaching. Students' academic performance is considered as a product of his learning and for information on individual learning rate one should refer to his visible behavior or to be more precise see his 
performance. Academic performance according to Bell, cited by Isah (2015) is a measurement of success or how well as student meets standards set out by the institution itself. Academic performance is how students deal with their studies and how they cope with or accomplish different tasks given to them by their teachers, it is also the ability to study and remember facts and being able to communicate your knowledge verbally or down on paper (Siva in Isah 2015). Seif, (2009) believed that students' academic performance is highly affected by motivation and emotion, environmental condition, tiredness and illness. So, these factors may yield a fairly accurate indicator of how much he is learning, unless he can show it well.

Academic performance of students can be regarded as the observable and measurable behaviour of a student in a particular situation (Adamu 2015). He further that the academic performance of a student in social studies includes observable and measurable behaviour of student at any point in time during a course. Bruce and Neville in Adamu (2015) opined that academic performance measures the aspect of behaviour that can be observed at a specific period. This can be obtained with the use of either teacher-made test or standardized achievement test developed for school subjects. In Business education academic performance consists of individual scores at any particular time obtained from either a teacher-made test or a standardized examination.

Business education in view of Jubril cited by Ibrahim (2014) is a specialized area of vocational education that provides educational training, skills development, attitudes adjustment towards business orientation and academic challenges. According to Azuka, Nwosu, Kanu and Agomuo (2006) and Odah and Ogbaga (2010), unlike general education which is long in theory and short in fact, Business Education is practical oriented and provides individuals with skills in business-related occupations such accounting, marketing and office occupation. Bilyaminu (2011) affirmed that business education as an aspect of total education programme that provides the knowledge, skills, attitudes and understanding needed to perform in the business world as a producer and/or consumer of goods and services. Business education can be defined as a programme designed to provide students with the basic processes of educational training; the philosophy, theory, decision making; and psychology of management; practical applications; business start-up and operational procedures. The fact is that without educational facilities, teacher cannot have effective teaching without adequate educational facilities. The condition of facilities in a learning environment determines teachers' and students' performance because if facilities are inadequate or dysfunctional, the learning process would be impaired and academic productivity will decrease (Elisu, Abdul-Razak \& Isaac 2016). It is against this background that this study examines the impact of education on students' academic performance in business education.

\subsection{Statement of the Problem}

Educational facilities are the concrete and non-concrete materials which the lecturers used to make his or her lesson more practical meaningful and permanent. Educational facilities increase the effectiveness of teaching by helping the students to assimilate ideals in a more meaningful and interesting manner. Facilities like modern laboratories, libraries, lecture rooms and other relevant resources are the educational faculties that need to put in place in order to ensure better performance of students (Bandele, 2003).

The problem of this study is the poor academic performance of student in business education and it is attributed inadequate educational facilities such as irrelevant instructional materials, conducive environment, inadequate facilities, old structures, inadequate instructional materials and unqualified staff there by making the system ineffective (Yala \& Wanjohi, 2011). It is observed that there is a high rate of indiscipline among tertiary institution students as many of them believed that absence from lectures, rudeness to institution authority, deliberate physical harm to others, forgery, cheating in examination are the right attitude. Adesola (2005) found out that the level of available resources is indeed a plus to the lecturers and it improves the commitment of the lecturers toward effective delivery of lecture. However, it is unfortunate that the educational facilities available in our institutions are old, chairs, machine and equipments and so on which are affecting the academic performance of students. Ayodele, (2000) affirmed that institutions where there is no well equipped library the student will be affected negatively because there will be no consulting venue for them. Adewuyi (2002) submitted that conducive learning environment can have effect on both the attitudes and achievement of students. He further added that a positive learning environment is found to be a 
very important factor of institution effectiveness. Therefore, it is against this background this study examine the impact of educational facilities on academic performance of students in business education.

\subsection{Purpose of the Study}

The purpose of this study is to examine the availability of educational facilities to improve academic performance of students in Business Education in College of Education, Ikere Ekiti. Specifically, the study sought to:

1. examine the library facilities that are available to improve academic performance of students.

2. examine the available facilities for teaching and learning of business education students to improve academic performance

\subsection{Research Questions}

The following research question were answered

1. What are the library facilities available to improve academic performance of students?

2. What are the available facilities for teaching and learning of business education students to improve academic performance?

\section{METHODOLOGY}

The descriptive research design of a survey was adopted for the study. The population of the study was made up of 374 Business education students in College of Education, Ikere Ekiti. The sample of the study was 100 Business Education students selected using simple random sampling technique. A well-structured questionnaire was the instrument used for the study, the questionnaire items were structured in a four-point Likert rating scale and it was validated by experts for face structure. The reliability of the instrument was determined through a pilot-test conducted on the instrument. The reliability coefficient of 0.62 was obtained using the Cronbach alpha coefficient which indicated that the instrument was reliable to collect the necessary data for the study. Descriptive statistics was used to analyze the research questions.

\subsection{Results of Findings}

\subsubsection{Descriptive Statistics}

Research question 1: What are the library facilities available to improve academic performance of students?

Table1. Library facilities available to improve academic performance of students

\begin{tabular}{|c|c|c|c|c|c|c|c|}
\hline $\mathbf{S} / \mathbf{N}$ & ITEMS & $\mathbf{S A}$ & $\mathbf{A}$ & $\mathbf{D}$ & SD & Mean & Remarks \\
\hline 1. & $\begin{array}{l}\text { There are adequate non-book materials to } \\
\text { meet the educational needs in the library }\end{array}$ & $\begin{array}{l}10 \\
(10 \%)\end{array}$ & $\begin{array}{l}15 \\
(15 \%)\end{array}$ & $\begin{array}{ll}30 \\
(30 \%)\end{array}$ & \begin{tabular}{|l|l}
45 \\
$(45 \%)$
\end{tabular} & 1.90 & Disagreed \\
\hline 2. & $\begin{array}{l}\text { There is adequate Computer facilities } \\
\text { provided for academic work }\end{array}$ & $3(3 \%)$ & $5(5 \%)$ & $\begin{array}{ll}50 \\
(50 \%)\end{array}$ & $\begin{array}{l}42 \\
(42 \%)\end{array}$ & 1.69 & Disagreed \\
\hline 3. & Air conditioners are adequately available & - & - & $\begin{array}{ll}40 \\
(40 \%)\end{array}$ & $\begin{array}{l}60 \\
(60 \%)\end{array}$ & 1.40 & Disagreed \\
\hline 4. & $\begin{array}{l}\text { Current printed materials are available and } \\
\text { accessible for learners }\end{array}$ & $4(4 \%)$ & $\begin{array}{ll}16 \\
(16 \%)\end{array}$ & $\begin{array}{ll}41 \\
(41 \%)\end{array}$ & $\begin{array}{ll}39 \\
(39 \%) \\
\end{array}$ & 1.81 & Disagreed \\
\hline 5. & $\begin{array}{l}\text { Adequate internet /ICT facilities are } \\
\text { available in this institution for students } \\
\text { research, hence increase their learning and } \\
\text { performance. }\end{array}$ & $\begin{array}{ll}10 \\
(10 \%)\end{array}$ & $\begin{array}{ll}20 \\
(20 \%)\end{array}$ & $\begin{array}{ll}30 \\
(30 \%)\end{array}$ & $\begin{array}{l}40 \\
(40 \%)\end{array}$ & 2.00 & Disagreed \\
\hline 6. & $\begin{array}{l}\text { Available library give room to perform } \\
\text { real-time interaction in the social space }\end{array}$ & $\begin{array}{ll}12 \\
(12 \%)\end{array}$ & $8(8 \%)$ & $\begin{array}{ll}48 \\
(48 \%)\end{array}$ & $\begin{array}{l}32 \\
(32 \%)\end{array}$ & 2.00 & \begin{tabular}{|l|} 
Disagreed \\
\end{tabular} \\
\hline 7. & $\begin{array}{l}\text { Business education Laboratory facilities } \\
\text { are adequate for practical exercise, hence } \\
\text { increases students' understanding and } \\
\text { performance of students }\end{array}$ & $7(7 \%)$ & $\begin{array}{l}11 \\
(11 \%)\end{array}$ & $\begin{array}{ll}58 \\
(58 \%)\end{array}$ & $\begin{array}{l}24 \\
(24 \%)\end{array}$ & 2.01 & Disagreed \\
\hline & Grand mean & & & & & 1.97 & \begin{tabular}{|l} 
Disagreed \\
\end{tabular} \\
\hline
\end{tabular}

$\bar{X} \leq 2.50$ indicate Agreed otherwise "Disagreed" 
Availability of Educational Facilities to Improve Academic Performance of Students in Business Education

The result in table 1 revealed the available library facilities to enhance students' academic performance. $75 \%$ of the respondents disagreed that there are adequate non-book materials to meet the educational needs in the library, $93 \%$ of the respondents also revealed that there is no adequate Computer facilities provided for academic work, $100 \%$ of the respondents indicated that Air conditioners are not adequately available in their institution library, $80 \%$ of the respondents disagreed that current printed materials are available and accessible for learners, $70 \%$ of the respondents showed that no adequate internet /ICT facilities are available in this institution for students" research, hence increase their learning and performance, $80 \%$ of the respondents disagreed that available library give room to perform real-time interaction in the social space, and 80 of the respondents also disagreed that business education laboratory facilities are adequate for practical exercise, hence increases students' understanding and performance of students. Hence, the result implies that library facilities available in college of education Ikere Ekiti is not adequate to improve academic performance of students.

Research question 2: What are the available facilities for teaching and learning of business education students to improve academic performance?

Table2. Available facilities for teaching and learning of business education students to improve academic performance

\begin{tabular}{|c|c|c|c|c|c|c|c|}
\hline $\mathbf{S} / \mathbf{N}$ & ITEMS & $\mathbf{S A}$ & $\mathbf{A}$ & D & SD & Mean & Remarks \\
\hline 1 & $\begin{array}{l}\text { Projectors are used in this institution } \\
\text { especially in business education department } \\
\text { to teach in order to increase the students } \\
\text { academic performance }\end{array}$ & $\begin{array}{l}11 \\
(11 \%)\end{array}$ & $9(9 \%)$ & $38(38 \%)$ & $\begin{array}{l}42 \\
(42 \%)\end{array}$ & 1.89 & Disagreed \\
\hline 2 & $\begin{array}{l}\text { Audio and Video visual disc are adequately } \\
\text { available for teaching and learning practical } \\
\text { work of business education students to } \\
\text { improve learning and performance }\end{array}$ & $4(4 \%)$ & $6(6 \%)$ & $51(51 \%)$ & $\begin{array}{l}39 \\
(39 \%)\end{array}$ & 1.71 & Disagreed \\
\hline 3 & $\begin{array}{l}\text { Computer sets are adequate for teaching and } \\
\text { learning of business education students to } \\
\text { increase their learning and performance. }\end{array}$ & $\begin{array}{l}14 \\
(14 \%)\end{array}$ & $8(8 \%)$ & $57(57 \%)$ & $\begin{array}{l}21 \\
(21 \%)\end{array}$ & 2.15 & Disagreed \\
\hline 4 & $\begin{array}{l}\text { Instructional materials and modern } \\
\text { equipments are adequately provided to } \\
\text { enhances teaching in the lecture room for } \\
\text { better understanding of students }\end{array}$ & $\begin{array}{l}10 \\
(10 \%)\end{array}$ & $3(3 \%)$ & $43(43 \%)$ & $\begin{array}{l}44 \\
(44 \%)\end{array}$ & 1.79 & Disagreed \\
\hline 5 & $\begin{array}{l}\text { Well-furnished lecture halls for students } \\
\text { comfort-ability are adequately provided to } \\
\text { improve their performance }\end{array}$ & $\begin{array}{l}45 \\
(45 \%)\end{array}$ & $\begin{array}{l}30 \\
(30 \%)\end{array}$ & $10(10 \%)$ & $\begin{array}{l}15 \\
(15 \%)\end{array}$ & 3.05 & Agreed \\
\hline & \multicolumn{5}{|l|}{ Grand Mean } & 2.12 & Disagreed \\
\hline
\end{tabular}

\section{$\bar{X} \leq 2.50$ indicate Agreed otherwise "Disagreed"}

The result in table 2 revealed the available facilities for teaching and learning of business education students to improve academic performance. $80 \%$ of the respondents disagreed that Projectors are used in this institution especially in business education department to teach in order to increase the students' academic performance, $90 \%$ of the respondents indicated that disagreed that Audio and Video visual disc are adequately available for teaching and learning practical work of business education students to improve learning and performance, $78 \%$ of the respondents revealed that Computer sets are not adequate for teaching and learning of business education students to increase their learning and performance, $87 \%$ of the respondents showed that no instructional materials and modern equipments adequately provided to enhances teaching in the lecture room for better understanding of students. However, $75 \%$ of the respondents agreed that there are well-furnished lecture halls for students' comfort-ability are adequately provided to improve their performance. Hence, the results showed that teaching and learning facilitates to enhance students' academic performance are not adequately available for business education students in College of Education, Ikere.

\section{DISCUSSIONS OF FINDINGS}

The findings of the study revealed that there are adequate non-book materials to meet the educational needs in the library, no adequate Computer facilities provided as well as no Air conditioners available 
in their institution library, inadequate current printed materials, no adequate internet/ICT facilities available in this institution for students ' research, available library give no room to perform real-time interaction in the social space, and business education laboratory facilities are not equipped for practical exercise. Based on this outcome, there is no doubt that inadequate library contribute to the poor academic performance of students in the college. This is in line with Emakuma cited by Osuji, Miriam, and Jiya (2019) who says that educational facilities become important because of the extent that it helps in improving teaching-learning effectiveness.

The study further revealed that no projectors, Audio and Video visual disc, computer sets with internet, instructional materials and modern equipments. All these have great impact on the students' performance. Adeboyeje (2000) adds that learning facilities are mandatory in order to make the institution a pleasant, safe and comfortable centre that will increase students' attendance, motivation and willingness to participate adequately in both curricula and co-curricular activities.

\section{CONCLUSION AND RECOMMENDATIONS}

Based on the findings of the study, it was concluded that there is no adequate educational facilities to enhance effective teaching and learning in order to improve students' academic performance. Modern equipment such as projector, computer, lecture clips for practical work are not use by most of the lecturers to enhance performance of students in business education. Therefore this study recommends that adequate educational facilities should be made available in the institution in order to guarantee better academic performance of business education students, also all the lecturers should make sure modern technologies such as projector, lecture clips, and adequate instructional materials are used to teach students for better understanding of course contents.

\section{REFERENCES}

[1] Adamu, N. (2015). Impact of Learning Environment on the Performance of Students in Social Studies in Junior Secondary Schools in Taraba State, Nigeria. Unpublished project

[2] Adeboyeje, R.A (2000). A practical approach to effective utilization and maintenance of physical facilities in secondary schools, In J.O. Fadipe and E.F. Oluchukwu

[3] Adesola, A.A. (2005). Resource Provision and Utilization, Mathematics Ability and learning Environment as prediction of learning Outcome in Undergraduate Practical Geography. Unpublished Ph.D Thesis, University of Ibadan, Ibadan.

[4] Adewuyi, D.A. (2002). Comparison between School Effectiveness, Characteristics and development Classroom Instruction Strategies in the United States and Nigeria. Journal for African, 27 (1 and 2), 263287.

[5] Ayodele, J.B. (2000). School size, class size and teacher's quality as correlation of internal efficiency in primary school in Ondo State, Nigeria. PhD's Thesis. University of Ibadan, Nigeria.

[6] Azuka, E.B., Nwosu, B.O., Kanu, I.N. and Agomuo, E.E. (2006) Foundation of Business Education in Nigeria. Data word Publications, Aba.

[7] Bandele, S.O. (2003). The Universal Basic Education in Perspective, Need for Formative Evaluation. Nigeria Journal of Educational Research and Evaluation, 1(4), 54-56

[8] Bilyaminu A. (2011), the Role of Entrepreneurship on Economic Growth. (Unpublished)

[9] Cotton, T. (2001). The Walls Speak: the interplay of quality facilities, school climate, and student achievement. Journal of Educational Administration, 46 (1), 55-73. http://dx.doi.org/1 $0.1108 / 09578230810849817$

[10] Eliasu I, Abdul-Razak, A. \& Isaac, J. W. (2016) State of academic facilities and its influence on Teachers' job stress in Tamale polytechnic. African Journal of Business Management. 10(2), 24-31

[11] Ibrahim, A. (2014) Assessment Of Adequacy Of Business Education Curriculum Content On University Students Acquisition Of Requisite Skills For Job Opportunities In Nigeria.

[12] Isah, H. (2015). Influence of Academic Self-Concept, Attitudes and Compliance on Academic Performance of Secondary School Students In Gombe State. Unpublished Thesis

[13] Lewis, M. (2001). Facility conditions and student test performance in the Milwaukee public schools. Scottsdale, AZ: Council of Educational Facility Planners International.

[14] Odah, T.N. and Ogbaga, F. (2010) Issues, Challenges and the Way forward. Ebonyi Technology and Vocational Educational Journal, 1, 55-60. 
[15] Osuij J.N (2016). Impact of School Facilities on Students' Academic Performances in Public secondary Schools in Giwa and Zaria Education zones, Kaduna State, Nigeria. Unpublished project

[16] Osuji, J.N., Miriam, O. E. \& Jiya S. J. (2019). Impact of Teaching and Learning Facilities on Students' Academic Performance in Public Secondary Schools in Giwa And Zaria Education Zones, Kaduna State. Nigeria

[17] Seif, A.A, (2009). Educational Psychology. Tehran, Payam Noor University Press.

[18] Stricherz, M. (2000). Bricks and mortarboards. Education Week 20(14): 30-32.

[19] Yala,P.O.\& Wanjohi,W.C.(2011). Performance Determinants of KCSE in Mathematics in Secondary Schools in Nyamira Division, Kenya. Asian Social Science, 7(20), 107-112.

\section{AUTHOR'S BIOGRAPHY}

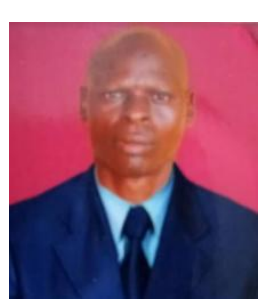

Olayemi, A.E is a lecturer in the School of Vocational and Technical Education, Department of Business Education, College of Education, Ikere Ekiti, Ekiti State.

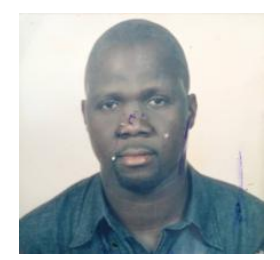

Ige, S.M is an instructor in the School of Vocational and Technical Education, Department of Business Education, College of Education, Ikere Ekiti, Ekiti State

Citation: Olayemi, A.E, Ige, S.M. "Availability of Educational Facilities to Improve Academic Performance of Students in Business Education" International Journal of Humanities Social Sciences and Education (IJHSSE), vol 7, no. 7, 2020, pp. 102-107. doi: http://dx.doi.org/10.20431/2349-0381.0707012.

Copyright: () 2020 Authors. This is an open-access article distributed under the terms of the Creative Commons Attribution License, which permits unrestricted use, distribution, and reproduction in any medium, provided the original author and source are credited. 